UDC 811.111

DOI https://doi.org/10.32447/2663-340X-2019-5-30

\title{
THE CHARACTERISTICS OF ENGLISH TERMS STRUCTURE IN TOURISM INDUSTRY
}

\author{
Yurko Nadiya Anatoliyivna \\ Senior Lecturer at the Department of Ukrainian and Foreign Languages \\ Lviv State University of Physical Culture named after Ivan Boberskyi \\ Kostiushko Street, 11, Lviv, Ukraine \\ Styfanyshyn Iryna Mykolayivna \\ Senior Lecturer at the Department of Ukrainian and Foreign Languages \\ Lviv State University of Physical Culture named after Ivan Boberskyi \\ Kostiushko Street, 11, Lviv, Ukraine
}

Romanchuk Olga Vasylivna

PhD in Philology,

Associate Professor at the Department of Ukrainian and Foreign Languages

Lviv State University of Physical Culture named after Ivan Boberskyi

Kostiushko Street, 11, Lviv, Ukraine

\begin{abstract}
The article deals with structural typology in professional tourism terminology. Modern linguists pay great attention to the study of tourism terminology as one of the most progressive industries in the world. Tourism has become one of the crucial phenomena of modern society greatly because of its association with language. Due to its being the language of international communication, the diversity of ways in which English language relates to tourism has attracted much research. The rapid growth of foreign terms in tourism terminological system requires its study, description and systematization.

The current body of research provides clear evidence of much attention being paid to the travel industry itself, and its terminology in particular. The structural potential of professional terms have also been the focus of scientific analysis. All the same, the characteristic features of English terms structure in tourism industry remain rather unexplored yet.

Considering the growing necessity of investigating the structure of international travel terminology and its evident gaps in English tourism terms, the research aimed to study the characteristics of English terms structure in the field of tourism. The task of the research was to compare the structural features and identify the quantitative ratio of components in tourism terms. Consequently, the object of research was the English terminology of tourism industry, and the subject concerned the structural peculiarities of the English tourism terms.

English samples of tourism terms from printed and internet resources have been analysed. Structural peculiarities of English tourism terms have been studied and defined by the methods of comparative and structural analysis. Further research perspectives in the professional terminology of tourism industry have been determined.

Key words: structural typology, professional terms, characteristic features, English terminology, tourism industry.
\end{abstract}

Introduction. Tourism is one of the most exciting and progressive industries in the world, that influences almost every other industry. Everyone gains from properly managed tourism. The tourism industry, in general, is the total of all businesses that directly provide goods or services to facilitate business, pleasure and leisure activities.

The concept of tourism is the subject of an interdisciplinary study, attracting specialists from various fields. The specialists' concerns in defining and explaining a lot of implications of tourism on the

(C) Yurko N. A., Styfanyshyn I. M., Romanchuk O. V. The characteristics of english terms structure in tourism industry economy have led to the shaping of a rich theory dealing with this field of activity, theories that try to present alongside the basic concepts with which it operates in practice a series of peculiarities, methodologies for measuring specific phenomena [9].

Tourism has become one of the central phenomena of a post-modern society greatly owing to its liaison with language. Being the global lingua franca, English language monopolizes all negotiations and transactions that take place in a tourist destination. The variety of ways in which English language relates to tourism has attracted much attention [5]. 
Theoretical framework. The tourism industry is advancing at increased pace. Rising cooperation between foreign companies and growing communication in the field of international travel industry determines the significance of the study on the tourism terminological system.

The overall spread of English as a language of intercultural communication has led to its becoming the terminology basis in many areas of science, including the tourist service sphere. Some new terms regularly appear and come to use. The rapid growth of foreign terms in tourism terminological system requires its study, description and systematization.

The current body of research provides clear evidence of much attention being paid to the travel industry $[10 ; 12]$ itself, and its terminology $[3 ; 5 ; 8$; $9 ; 11 ; 13]$ in particular. The structural potential of professional terms have also been the focus of scientific analysis $[1 ; 4 ; 14]$. Nevertheless, the characteristic features of English terms structure in tourism industry have not been explored enough.

The purpose of the study. Due to growing necessity of investigating the structure of international travel terminology and its evident gaps in English tourism terms, the aim of the research is to study the characteristics of English terms structure in the field of tourism.

Evident impossibility to convey all concepts and phenomena of such a widespread industry with one-component (meaning one root stem) terms generated the formation of complex (two- and more component) terms.

It is the task of our research to compare the structural features and identify the quantitative ratio of components in tourism terms.

Consequently, the object of research is the English terminology of tourism industry, and the subject concerns the structural peculiarities of the English tourism terms.

Methods of research: literature analysis, comparative method and method of structural analysis.

The research database is represented by the sample of English tourism terms from the printed $[2 ; 7]$ and internet resources [6].

Research findings. The first issue to be examined was a quantitative ratio of the studied terms components. It is noteworthy that root morphemes, prepositions and conjunctions, but not articles were considered as components. Results of the structural analysis appeared to be the following:

- $23.2 \%$ - one-component terms (accommodation, apartment, arrival, available, baggage, booking, cabin, camping, cancellation, catering, confirmation, cruise, cuisine, customs, departure, destination, dining, excursion, fare, fee, furnishing, guest, guide, hiking, hospitality, hotel, hostel, insurance, itinerary, journey, landing, luggage, map, occupancy, passenger, porter, reception, service, ticket, visitor, waiter, etc);

- 56.4\% - two-component terms (additional charge, arrival time, bargain price, beach holiday, boat trip, booking agent, business facilities, business trip, butler service, cable car, cancel a reservation, car hire, check-in, check-out, children's facilities, city break, coach trip, conference facilities, day trip, departure time, domestic flight, double room, dutyfree, early booking, entrance fee, excess baggage, expiry date, familiarization trip, flight attendant, full board, gift shop, get around, go camping, go hiking, green tourism, guided tour, half board, high season, hotel chain, hotel room, incentive tourism, information desk, junior suite, key card, late arrival, laundry service, low season, mass tourism, open bar, package tour, reception desk, scheduled flight, tourist attraction, urban tourism, valet service, wedding trip, youth hostel, etc);

- $14.3 \%$ - three-component terms (amenities and facilities, apply for a visa, book in advance, check-out time, computer reservation system, credit card payment, duty-free store, ecology-minded traveller, family-run hotel, fixed price menu, goods on offer, guarded car park, influx of tourists, king-sized bed, last minute offer, long-haul destination, loss damage waiver, low-cost travel, means of transport, natural beauty area, off-season period, place of interest, refusal of admission, self-catering apartment, tourist information office, visa-free entry, wake-up service, etc);

- $5.2 \%$ - four-component terms (country of temporary residence, cover of tourist losses, full board and lodging, generally accepted quality standards, lodging and food facilities, record of hotel bills, set out on a journey, etc).

Terminological units with more than four components are rather occasional and account for less than $1 \%$ of the terms sample.

The above data clearly illustrate the prevalence of two-component English terms in tourism industry. Such an obvious prevalence is naturally predetermined by the commonly recognized claiming that two-component terms are the most optimal by quantity, as the term requirements contradiction in its conciseness and precision are the least peculiar for them.

Other aspects under research were structural types of English terms formation in the field of tourism. The study findings suggest that English complex terms of tourism industry tend to be formed as follows.

The structural types of two-component tourism terms:

- $\mathrm{N}+\mathrm{N}$ (arrival time, beach holiday, boat trip, business facilities, business trip, butler service, car hire, city break, coach trip, conference facilities, day trip, departure time, entrance fee, expiry date, familiarization trip, flight attendant, gift shop, hotel chain, hotel room, information desk, key card, laundry service, package tour, reception desk, tourist attraction, valet service, youth hostel, etc.);

- Adj+N (additional charge, domestic flight, early booking, excess baggage, full board, green tourism, high season, incentive tourism, junior suite, late arrival, low season, mass tourism, open bar, urban tourism, etc.); 
- $\mathrm{V}+\mathrm{N}$ (cancel a reservation, go camping, go hiking, etc.);

- $\quad \mathrm{P} 2+\mathrm{N}$ (guided tour, scheduled flight, etc.);

- Num+N (double room, half board, etc.);

- N+Prep (check-in, check-out, etc.);

- $\mathrm{N}+$ Adj (duty-free, etc.).

The structural types of three-component tourism terms:

- $\mathrm{N}+\mathrm{N}+\mathrm{N}$ (computer reservation system, credit card payment, loss damage waiver, tourist information office, etc.);

- $\mathrm{N}+\mathrm{Prep}+\mathrm{N}$ (goods on offer, influx of tourists, means of transport, place of interest, refusal of admission, etc.);

- $A d j+\mathrm{N}+\mathrm{N}$ (long-haul destination, low-cost travel, natural beauty area, etc.);

- $\mathrm{N}+\mathrm{P} 2+\mathrm{N}$ (ecology-minded traveller, family-run hotel, king-sized bed, etc.);

- $\mathrm{P} 2+\mathrm{N}+\mathrm{N}$ (fixed price menu, guarded car park, etc.);

- $\mathrm{V}+\operatorname{Prep}+\mathrm{N}$ (apply for a visa, book in advance, etc.);

- $\mathrm{N}+\mathrm{Adj}+\mathrm{N}$ (duty-free store, visa-free entry, etc.);

- $\mathrm{N}+\mathrm{Conj}+\mathrm{N}$ (amenities and facilities, etc.).

The structural types of four-component tourism terms:

- $\mathrm{N}+$ Prep $+\mathrm{N}+\mathrm{N}$ (cover of tourist losses, record of hotel bills, etc.);

- $\mathrm{N}+\mathrm{Conj}+\mathrm{N}+\mathrm{N}$ (lodging and food facilities, etc.);

- $\mathrm{N}+\mathrm{Prep}+\mathrm{Adj}+\mathrm{N}$ (country of temporary residence, etc.);
- $\quad \operatorname{Adj}+\mathrm{N}+\mathrm{Conj}+\mathrm{N}$ (full board and lodging, etc.);

- $\mathrm{Adv}+\mathrm{P} 2+\mathrm{N}+\mathrm{N}$ (generally accepted quality standards, etc.);

- $\mathrm{V}+$ Prep+Prep+N (set out on a journey, etc.).

As we see, the most productive structural component here is that of a noun. The reasonable explanation for this apparent tendency of a substantive component to be the most productive in the structural types of English tourism terms lies in the fact that noun is one of the most widespread parts of speech in any professional terminology, notably in the field of international travel and communication.

Conclusions. On the grounds of the above research outcomes the following conclusions can be made:

- The rapid growth of foreign terms in tourism terminological system requires its study, description and systematization.

- Being a significant aspect of any terminology, the structural peculiarities of English tourism terms have not been currently researched enough.

- Two-component English terms appear to clearly prevail in the field of tourism corresponding with the term requirements for conciseness and precision.

- The evident tendency of substantive component to be the most productive in English tourism terms is due to the fact that noun is a widespread part of speech in any professional terminology, particularly in the travel industry.

The perspectives of further research are the terms systematization and compiling a tourism glossary considering the structural peculiarities of its terms.

\section{ЛІТЕРАТУРА}

1. Компонентно-структурний аналіз англомовних абревіатур у спортивній лексиці / О. В. Романчук, О. В. Матвіяс, У. М. Проценко, І. М. Стифанишин, Н. А. Юрко. Функциональная лингвистика. 2011. № 2, т. 2. С. 167-169.

2. Мальська М. П., Микитенко Н. О., Котловський А. М. Англо-український словник термінів сфери туризму : навч. посіб. Київ : Центр учбової літератури, 2015. 448 с.

3. Матвіяс О. В., Романчук О. В., Базиляк Н. О. Комплексні фразеологічні одиниці у термінологічній системі галузі туризму. Наукові записки Національного університету «Острозька академія». Серія «Філологічна». 2016. Вип. 60. С. 184-187.

4. Структурні особливості термінів гандболу в англійській мові / О. В. Романчук, О. В. Матвіяс, І. М. Стифанишин, Н. А. Юрко. Функциональная лингвистика. 2010. № 1, т. 2 С. 205-206.

5. Fox R. English in tourism: a sociolinguistic perspective. Tourism and Hospitality Management. 2008. Vol. 14, No. 1. P. $13-22$.

6. Beaver A. Oxford Dictionary of Travel and Tourism. Oxford: OUP, 2012. URL: http://www.oxfordreference.com/ view/10.1093/acref/9780191733987.001.0001 (accessed: 11.04.2019).

7. Medlik S. Dictionary of travel, tourism and hospitality. Oxford: Butterworth-Heinemann, 2003. 283 p

8. Skibitska O. The Language of Tourism: Translating Terms in Tourist Texts. Translation Journal. 2015. Vol. 18, No. 4. URL: https://translationjournal.net/October-2015/the-language-of-tourism-translating-terms-in-tourist-texts.html (accessed: 11.04.2019).

9. Stoyanova S. R. Terminological System of Tourism in the Aspect of Intercultural Communication Exemplified by the Russian Language. Advances in Social Science, Education and Humanities Research: Proceedings of the 5th International Conference on Education, Language, Art and Inter-cultural Communication. December, 2018. Atlantis Press. Vol. 289. P. 344-349. URL: https://doi.org/10.2991/icelaic-18.2018.77 (accessed: 11.04.2019).

10. Study a language abroad without a broad expenditure / A. Antonova, O. Voznyi, N. Yurko, I. Styfanyshyn. День студентської науки: зб. тез доп. за результатами щоріч. наук. конф. студентів ЛДУФК. 2017. C. 181-183. URL: http://repository.ldufk.edu.ua/handle/34606048/9347 (дата звернення: 11.04.2019).

11. The main features of English synonyms in tourism industry (based on the pre-intermediate coursebook English for International Tourism) / A. Antonova, A. Zadorozhnya, N. Yurko, U. Protsenko. День студентської науки: зб. тез 
доп. за результатами щоріч. наук. конф. студентів ЛДУФК. 2016. С. 103-104. URL: http://repository.ldufk.edu.ua/ handle/34606048/6492 (дата звернення: 11.04.2019).

12. Why tourism? The World Tourism Organization UNWTO : website. URL: http://www2.unwto.org/content/ why-tourism (accessed: 11.04.2019).

13. Yurko N. A. Abbreviations in tourism industry: the main peculiarities of structural components. Актуальні питання наукових досліджень: матеріали XLIII Міжнар. наук.-практ. конф., Чернівці, 29-30 червня 2016 р. T. 2. Київ: Лабораторія думки, 2016. С 9-11.

14. Yurko N. A., Protsenko U. M., Litkevych O. A. The Peculiarities of English Terms Structure in Track and Field. Здоров'я людини у сучасному суспільстві: матеріали Міжнар. наук.-практ. конф., 14-16 червня 2012 р. Сімферополь: Кримський інститут бізнесу. С. 124-126.

\section{REFERENCES}

1. Romanchuk, O. V., Matviyas O. V., Protsenko, U. M., Styfanyshyn, I. M., \& Yurko, N. A. (2011). Komponentno-strukturnyi analiz anglomovnykh abreviatur u sportyvniy leksytsi [Componential and structural analysis of English sports abbreviations]. Funktsionalnaya lingvistika, vol. 2, no. 2, pp. 167-169 [in Ukrainian].

2. Malska, M. P., Mykytenko, N. O., \& Kotlovskyi A. M. (2015). Anglo-ukrayinskyi slovnyk terminiv sfery turysmu : navchalnyi posibnyk. [English-Ukrainian dictionary of tourism terms: manual]. Kyiv: Tsentr uchbovoyi literatury [in Ukrainian].

3. Matviyas O. V., Romanchuk, O. V., \& Bazylyak N. O. (2016). Kompleksni frazeolohichni odynytsi u terminolohichniy systemi haluzi turyzmu [Compound phrasal units in terminological system of tourism]. Naukovi zapysky Natsionalnoho Universytetu "Octrozka akademiya". Seriya "Filolohichna”, vol. 60, pp. 184-187 [in Ukrainian].

4. Romanchuk, O. V., Matviyas O. V., Styfanyshyn, I. M., \& Yurko, N. A. (2010). Strukturni osoblyvosti terminiv handbolu v anhliyskiy movi [Structural peculiarities of English handball terminology]. Funktsionalnaya lingvistika, vol. 1, no. 1, pp. 205-206 [in Ukrainian].

5. Fox, R. (2008). English in tourism: a sociolinguistic perspective. Tourism and Hospitality Management, vol. 14, no. 1, pp. 13-22 [in English].

6. Beaver, A. (2012). Oxford Dictionary of Travel and Tourism. Oxford: OUP. URL: http://www.oxfordreference.com/ view/10.1093/acref/9780191733987.001.0001 (accessed: 11.04.2019) [in English].

7. Medlik, S. (2003). Dictionary of travel, tourism and hospitality. Oxford: Butterworth-Heinemann [in English].

8. Skibitska, O. (2015). The Language of Tourism: Translating Terms in Tourist Texts. Translation Journal, vol. 18, no. 4. URL: https://translationjournal.net/October-2015/the-language-of-tourism-translating-terms-in-tourist-texts.html (accessed: 11.04. 2019) [in English].

9. Stoyanova, S. R. (2018). Terminological System of Tourism in the Aspect of Intercultural Communication Exemplified by the Russian Language. Proceedings of the Advances in Social Science, Education and Humanities Research: the 5th International Conference on Education, Language, Art and Inter-cultural Communication (ICELAIC December, 2018), vol. 289, pp. 344-349. URL: https://doi.org/10.2991/icelaic-18.2018.77 (accessed: 11.04.2019) [in English].

10. Antonova, A., Voznyi, O., Yurko, N., \& Styfanyshyn, I. (2017) Study a language abroad without a broad expenditure. Proceedings of the Den studentskoyi nauky: shchorichna naukova konferentsiya studentiv LDUFC (Ukraine, Lviv, April 27, 2016), pp. 181-183. URL: http://repository.ldufk.edu.ua/handle/34606048/9347 (accessed: 11.04.2019) [in English].

11. Antonova, A., Zadorozhnya, A., Yurko, N., \& Protsenko, U. (2016). The main features of English synonyms in tourism industry (based on the pre-intermediate coursebook English for International Tourism). Proceedings of the Den studentskoyi nauky: shchorichna naukova konferentsiya studentiv LDUFC (Ukraine, Lviv, April 28, 2016 ), pp. 103-104. URL: http://repository.ldufk.edu.ua/handle/34606048/6492 (accessed: 11.04.2019) [in English].

12. Why tourism? The World Tourism Organization UNWTO : website. URL: http://www2.unwto.org/content/ why-tourism (accessed: 11.04.2019) [in English].

13. Yurko, N. A. (2016). Abbreviations in tourism industry: the main peculiarities of structural components. Proceedings of the Topical Issues of Scientific Researches: XLIII International Scientific Conference (Ukraine, Chernivtsi, June 29-30, 2016), Kyiv: Laboratoriia dumky, pp. 9-11 [in English].

14. Yurko, N. A., Protsenko, U. M., \& Litkevych, O. A. (2012). The Peculiarities of English Terms Structure in Track and Field. Proceedings of the Zdorovya lyudyny v suchasnomu suspilstvi: Mizhnarodna naukovo-praktychna konferentsiya, (Ukraine, Simferopol, June 14-16, 2012), Simferopol: Krymskyi instytut biznesu, pp. 124-126 [in English]. 


\title{
СТРУКТУРНІ ХАРАКТЕРИСТИКИ ТЕРМІНІВ ТУРИЗМУ В АНГЛІЙСЬКІЙ МОВІ
}

\author{
Юрко Надія Анатоліївна \\ старший викладач кафедри украӥнської та іноземних мов \\ Львівського державного університету фізичної культури імені Івана Боберського \\ вул. Костюшка, 11, Львів, Украӥна \\ Стифанишин Ірина Миколаївна \\ старший викладач кафедри української та іноземних мов \\ Львівського державного університету фізичної культури імені Івана Боберського \\ вул. Костюшка, 11, Львів, Украӥна

\section{Романчук Ольга Василівна} \\ кандидат філологічних наук, \\ дочент кафедри української та іноземних мов \\ Львівського державного університету фізичної культури імені Івана Боберського \\ вул. Костюшка, 11, Львів, Украӥна
} Статтю присвячено дослідженню структурної типології галузевої термінології туризму. Сучасні лінг-
вісти приділяють велику увагу вивченню туристичної термінологї̈ як однієї з найбільш прогресивних галузей
у світі. Туризм став одним з найважливіших явищ сучасного суспільства, значною мірою завдяки його тісному
взаємозв язку із мовою. Будучи мовою міжнародного спілкування, англійська мова перебуває в иентрі уваги бага-
тьох досліджень. Швидке зростання іноземних термінів у галузевій терміносистемі туризму вимагає ї̈ деталь-
ного вивчення, опису та систематизації.
Аналіз літературних джерел очевидно свідчить про те, щзо велика увага дослідників приділяється самій
туристичній галузі, та ї̈ термінологї зокрема. Структурний потенціал професійних термінів також перебував
у центрі уваги наукового дослідження. Проте структурні характеристики термінів туризму в англійській мові
досі залишаються маловивченими.

Беручи до уваги необхідність структурного дослідження міжнародної туристичної термінології та її очевидні прогалини у туристичній термінології англійської мови, наше дослідження було спрямовано на вивчення структурних аспектів англійської термінології галузі туризму. Завданням дослідження було порівняння структурних особливостей та визначення кількісного співвідношення компонентів у туристичних термінах. Відповідно, об'єктом дослідження була англійська термінологія туристичної галузі, а предметом дослідження стали структурні особливості термінів туризму в англійській мові.

Проаналізовано вибірку англійських термінів туристичної сфери із друкованих та інтернет-ресурсів. методами порівняльного та структурного аналізу досліджено та визначено структурні особливості термінів туризму в англійській мові. Окреслено перспективні напрямки досліджень у галузі фахової термінології туризму.

Ключові слова: структурна типологія, галузеві терміни, характерні особливості, англійська термінологія, туристична індустрія. 